\title{
Effects of oxytetracycline and sulfachloropyridazine residues on the reductive activity of Shewanella decolorationis S12
}

\begin{abstract}
Effects of oxytetracycline (OTC) and sulfachloropyridazine (SCP), two of the widely used antibiotics in livestock production, on beneficial environmental microorganisms were studied. Shewanella decolorationis S12 was selected as the target bacteria for the role in reduction of $\mathrm{Fe}$ (III) and dye under anaerobic conditions. The results showed that the antibiotics significantly inhibited $\mathrm{Fe}(\mathrm{III})$ reduction and dye decoloration in the reduction system. The rates of $\mathrm{Fe}$ (II) formed (ī r) were 3.6 and $0.2 \mathrm{mg} / \mathrm{L} / \mathrm{day}$ for the OTC concentrations of $0 \overline{1} 1 \mathrm{mg} / \mathrm{L}$ and $1 \bar{i} 50 \mathrm{mg} / \mathrm{L}$, respectively, with $1 \mathrm{mg} / \mathrm{L}$ as the turning point of the inhibition effect. The turning point of inhibition effect was much higher for SCP treatments, at $4 \mathrm{mg} / \mathrm{L}$. The results also showed higher production values for adsorbed $\mathrm{Fe}(\mathrm{II})$ than soluble Fe(II) in OTC treatments, but the reverse occurred in the SCP treatments. The difference between the treatments could be due to higher sorption coefficients of OTC as compared to SCP. Transmission electron micrographs showed changes in cell structures of S. decolorationis S12 grown in medium with OTC. Detached cell walls and large vacuoles in internal cell contents were found in OTC-treated cells. The results of the present study indicated that the inhibition of antibiotic on the reduction activity of S. decolorationis S12 may be due to a decrease in live S. decolorationis S12 population and/or damages of their cell structure in this reduction system.
\end{abstract}

Keyword: Antibiotics; Oxytetracycline; Reductive activity; Shewanella decolorationis S12; Sulfachloropyridazine 